\title{
The Effect of Profenofos on the Nutritive Composition of Major Carp for Estimating Maximum Allowable Toxicant Concentration of the Pesticide
}

\author{
Ghazala Ghazala $^{1}$, Salma Sultana ${ }^{2}$, K. A. Al-Ghanim ${ }^{3}$, Shahid Mahboob ${ }^{2,3 *}$ \\ ${ }^{1}$ Department of Environmental Sciences, Government College University, Faisalabad, Pakistan \\ ${ }^{2}$ Department of Zoology, Government College University, Faisalabad, Pakistan \\ ${ }^{3}$ Department of Zoology, College of Science, King Saud University, Riyadh, Saudi Arabia
}

Received: 5 December 2017

Accepted: 22 February 2018

\begin{abstract}
Determining the influence of a sublethal concentration of the organophosphate pesticide profenofos on the proximate composition of muscle in Catla catla, Labeo rohita, and Cirrhinus mrigala was the aim of this study. Three sublethal concentrations of profenofos were given to the fish in three replicates for eight weeks. Moisture content exhibited a rapid increase in C. catla, L. rohita, and C. mrigala, with an increase in the dose of profenofos. Decreases in protein, fat, and carbohydrate contents were recorded against different sublethal doses of profenofos in C. catla, L. rohita, and C. mrigala compared to control fish. Ash contents exhibited no proper order of an increase or decrease in these fish species against the exposure of different doses of profenofos. It has been concluded that the maximum allowable toxicant concentration (MATC) endpoints for protein, fat, ash, and carbohydrate were more sensitive and may be successfully used as a new biomarker for monitoring early changes induced by pesticides. The findings of this study may be helpful for monitoring and regulatory agencies to develop a strategy against these important pollutants.
\end{abstract}

Keywords: pesticides, chronic, sublethal, carp, proximate

\section{Introduction}

Pesticides are unavoidable and are primarily used for crop protection against various insects, and play a vital role in increasing crop productivity. Pesticides cause various health hazards to humans and also

*e-mail: shahidmahboob60@hotmail.com pollute the soil, water, air, and food for several years [1]. Many types of research have been aimed at minimizing the application of pesticide usage through genetic engineering, integrated pest management, and biocontrol agents, but still pesticides are being applied in huge quantities in developing countries [2-3]. Profenofos is an organophosphorus pesticide that may be applied against the lepidopteran insects on different crops like cotton, maize, soybean, vegetables, and sugar beet [4]. 
Although pesticides are used against the targeted pests, they also have an effect on non-target organisms like invertebrates and fish in the aquatic ecosystem [5-7]. So fish can be successfully used as a model organism to understand the deleterious effects of pesticides.

Fish is considered the most economical source of animal protein in developing countries and is extensively cultured in inland water bodies. It is necessary to study the lethal effects of pesticides on hematology and biochemical alterations due to their deposition into various fish tissues and its after-effects on humans as an end user [2]. The lethal effects of organophosphorus and carbamates on fish can be studied by using different biomarkers like hematological, biochemical, and enzymological parameters [5, 7], and the changes in these parameters may be used as health indicators of fish [8]. The toxicity of these pesticides also affects normal body metabolism, which is directly or indirectly on the survival, susceptibility towards parasite, diseases, and growth of fish [7]. The influence of continuing exposure of pesticides on fish growth can be assessed either by RNA/DNA ratio or changes in important constituents like protein and fat to compensate the stress of chemical toxicants [3]. The presence of many pesticides has been reported in rivers and fish in the freshwater ecosystem [1].

Pesticides in the freshwater ecosystem affect different physiological and biochemical parameters of fish [1, 9-11]. Many researchers have mentioned a decrease in the body proximate composition of fish against different pesticides [10-12]. Aquatic pollution can cause various changes, ranging from biochemical changes in a single cell to alterations in the whole population. Generally, the various indicators are used in toxicity studies such as mortality, survival, and growth with acute toxicity tests. These parameters are quite useful for short-term studies, but for long-term sublethal concentrations these parameters are difficult to verify. The study was aimed at determining: (i) the impact of sublethal concentrations of profenofos on the proximate composition of Catla catla, Labeo rohita, and Cirrhinus mrigala and (ii) the maximum allowable toxicant concentration (MATC) of profenofos based on the proximate composition of fish muscle.

\section{Materials and Methods}

The specimen of Catla catla, Labeo rohita, and Cirrhinus mrigala (total length $90.12 \pm 6.10 \mathrm{~mm}$ and $31.22 \pm 2.44 \mathrm{~g}$ body weight) were procured from a local fish hatchery and transported in plastic containers to the laboratory. The specimens were acclimatized to laboratory conditions for two weeks in a tank with dechlorinated water. After acclimatization, 20 specimens of each species were stocked in glass aquaria (70L) before exposure with profenofos. Fish were given a fish feed diet (35\% crude protein) (a) 3\% of their body weight every 8 hours.
Profenofos $\quad 98 \% \quad$ [O-(4-Bromo-2-chlorophenyl) O-ethyl S-propyl phosphorothioate] was procured from a local supplier and dissolved in analyticalgrade methanol (Merck). At the 96-hour median lethal concentrations for profenofos were determined as $0.31 \mathrm{mg} / \mathrm{L}$ (0.26- 0.38), $0.19 \mathrm{mg} / \mathrm{L}$ (0.14- 0.24) and $0.21 \mathrm{mg} / \mathrm{L}(0.16-0.26)$ in L. rohita, C. catla, and C. mrigala, respectively. The solubility of profenofos was confirmed by dissolving one ppm concentration in the solvent and in the test water sample and confirmed through HPLC (Hitachi Model L7400).

The fingerlings of C. catla, L. rohita, and C. mrigala were treated to $0.038,0.019,0.012\left(1 / 5^{\text {th }}, 1 / 10^{\text {th }}\right.$, and $1 / 15^{\text {th }}$ part of $\left.\mathrm{LC}_{50}\right) ; 0.06,0.03,0.02\left(1 / 5^{\text {th }}, 1 / 10^{\text {th }}\right.$, and $1 / 15^{\text {th }}$ part of $\left.\mathrm{LC}_{50}\right)$ and $0.041,0.020$, and $0.013 \mathrm{mg} / \mathrm{L}\left(1 / 5^{\text {th }}, 1 / 10^{\text {th }}\right.$, and $1 / 15^{\text {th }}$ part of $\mathrm{LC}_{50}$ ) concentrations of profenofos in triplicate for 60 days, respectively. The water was renewed after every $24 \mathrm{hrs}$. The study was performed at an ambient temperature of $28 \pm 2^{\circ} \mathrm{C}$. The concentration of dissolved oxygen, $\mathrm{pH}$, and water temperature was recorded and monitored during the experimental period. The fish were exposed to profenofos in a static bioassay system and the control fish were also given carrier solvent only.

\section{RNA/ DNA Ratio}

After 60 days of exposure to sublethal concentrations of profenofos, 7 specimens of C. catla, L. rohita, and $C$. mrigala were procured from each treated aquaria and anesthetized with MS222, dissected to take the muscle tissue samples, and stored at $-20^{\circ} \mathrm{C}$ in the freezer. Nucleic acid was extracted by following the methods of [13].

\section{Proximate Analysis}

Seven C. catla, L. rohita, and C. mrigala fish from each treatment were collected for proximate analysis (moisture, crude protein, fat, and ash) by following standard procedures as described in [14]. Fish were dissected and muscle samples were separated, frozen in liquid nitrogen, and stored at $-20^{\circ} \mathrm{C}$. The percentage of carbohydrate was calculated as nitrogen-free extract as mentioned below:

$$
\begin{gathered}
\text { Percentage of carbohydrate } \\
=100-(\% \text { moisture }+ \text { protein }+ \text { fat }+ \text { ash }) \\
\text { Statistical Analysis }
\end{gathered}
$$

The treatment means of different parameters were analyzed through one-way analysis of variance by Minitab software. The differences among the test doses were compared by Tukey's HSD test.

On the basis of significant values obtained after analysis of variance, no observable effect concentration on the proximate composition (NOEC) and least observable effect concentration the changes in the 
proximate composition compared to control (LOEC) were worked out. The maximum allowable toxicant concentration (MATC) based on the NOEC and LOEC values - which a fish can tolerate for survival and reproduction without much effect on its metabolic activity level - was worked using the following formula:

$$
\text { MATC }=(\text { NOEC } x \text { LOEC })^{1 / 2}
$$

From this MATC value, the application factor was calculated using the formula of [15]:

$$
\mathrm{AF}=\mathrm{s} \frac{\mathrm{MATC}}{48 \mathrm{~h} \frac{\mathrm{LC}}{50}}
$$

The application factor (AF) worked out for one species may be used for other relevant species provided their $48 \mathrm{~h} \mathrm{LC50}$ is known [16].

\section{Results and Discussion}

Assessment of the biochemical parameters in fish and other organisms is broadly used to monitor the water contaminants and their effect on health conditions. Moreover, biochemical parameters have been used as biomarkers for toxicant exposure and resultant effects in fish [17]. Dissolved oxygen concentration was maintained at 5.00-5.50 mg/L. Electrical conductivity, $\mathrm{pH}$, and temperature of water ranged as $2.23-2.47 \mathrm{mS}$ and $7.5-8.5$ and $25^{\circ} \mathrm{C}-27^{\circ} \mathrm{C}$, respectively.

The average level of DNA as $0.75 \mu \mathrm{g} / \mathrm{mg}$ was recorded in $C$. catla given to $1 / 5^{\text {th }}$ of the $\mathrm{LC}_{50}$ of profenofos. The comparison of the means indicated highly significant differences $(\mathrm{P}<0.01)$ for an $\mathrm{RNA} /$ DNA ratio among the three test doses of profenofos compared to controls (Table 1). The highest RNA/ DNA was recorded as $8.753 \pm 0.02$ in control fish and the minimum ratio was observed as $1.567 \pm 0.01$ against the highest sublethal dose of profenofos. DNA concentration in C. catla ranged between $0.7-0.97 \mu \mathrm{g} / \mathrm{mg}$ (Table 1). The decrease in the RNA/DNA ratio was recorded in L. rohita in the order: control $>1 / 15$ th $>1 / 10$ th $>1 / 5^{\text {th }}$ against the exposure of profenofos control $>1 / 15^{\text {th }}>$ $1 / 10^{\text {th }}>1 / 5^{\text {th }}$, respectively. The significant differences
$(\mathrm{P}<0.01)$ were recorded among all the different doses of profenofos for RNA/ DNA ratio (Table 1). In L. rohita the maximum RNA and minimum DNA concentration were recorded in the control group. RNA value was declined compared to DNA and vice versa was noticed with an increase in the dose of profenofos. In C. mrigala the DNA concentrations were recorded as $0.57 \mu \mathrm{g} / \mathrm{mg}$, $0.93 \mu \mathrm{g} / \mathrm{mg}, 0.8 \mu \mathrm{g} / \mathrm{mg}$, and $0.67 \mu \mathrm{g} / \mathrm{mg}$ against control, $1 / 5^{\text {th }}, 1 / 10^{\text {th }}$, and $1 / 15^{\text {th }} \mathrm{LC}_{50}$-profenofos exposed groups, respectively (Table 1). Organophosphosphates (OP) might acted as strong inhibitor of DNA synthesis, which ultimately reduce the level of RNA in fish muscle. This might be due to electrophilic property, in which the OP pesticides attack many enzymes and disturb their metabolic pathways. RNA plays an important role in protein synthesis, hence it might cause a decrease in protein level. These findings were in line with the findings of [18-19], who reported a significant impact of quinalphos on an RNA/DNA ratio and protein content in the fish. Profenofos might have a significant effect on the transcription and translation of the protein contents in C. catla, L. rohita, and C. mrigala. The quantity of RNA is directly responsible in the protein synthesis and it varied with age, life-stage, fish size, health status, and the environment. Hence, fish in a controlled environment had higher RNA/DNA ratios compared to the treated groups.

C. catla, L. rohita, and C. mrigala were tested against three sublethal doses of profenofos 0.038, 0.019 , and $0.012 ; 0.06,0.03,0.02$, and 0.041 ; and 0.020 and $0.013 \mathrm{mg} / \mathrm{L}$, respectively. The sublethal doses of profenofos exhibited a significant effect on crude protein, moisture, fats, ash, and carbohydrate contents in C. catla, L. rohita, and C. mrigala. A rapid increase in moisture contents in these fish species was observed with an increase in the dose of profenofos. The maximum moisture contents were recorded as $87.82 \pm 0.01 \%$ in $C$. mrigala against the exposure of $0.041 \mathrm{mg} / \mathrm{L}$ of profenofos and exhibited a significant difference $(\mathrm{P}<0.01)$ compared to the control group $(80.05 \pm 0.02 \%)$ as presented in Table 2 . In L. rohita and C. catla, minimum moisture was observed as $77.17 \pm 0.06 \%$ and $76.70 \pm 0.03 \%$, respectively, in control fish. In $L$. rohita and C. catla an adverse effect on the water percentage was recorded in fish exposed to $0.06 \mathrm{mg} / \mathrm{L}$ and $0.038 \mathrm{mg} / \mathrm{L}$ of profenofos, respectively.

Table 1. Effect of sublethal concentrations of profenofos on RNA/DNA ratio ( \pm S.E.) in the muscle of major Indian carp.

\begin{tabular}{|c|c|c|c|c|c|c|c|}
\hline \multirow{5}{*}{ Profenofos } & Control & $\begin{array}{c}\text { Exposed } \\
\text { conc. }(\mathrm{ppm})\end{array}$ & Catla catla & $\begin{array}{c}\text { Exposed } \\
\text { conc. }(\mathrm{ppm})\end{array}$ & Labeo rohita & $\begin{array}{c}\text { Exposed } \\
\text { conc. (ppm) }\end{array}$ & $\begin{array}{c}\text { Cirrhinus } \\
\text { mrigala }\end{array}$ \\
\cline { 2 - 8 } & 0.00 & $8.77 \pm 0.02 \mathrm{~A}$ & 0.00 & $9.95 \pm 0.02 \mathrm{~A}$ & 0.00 & $6.74 \pm 0.05 \mathrm{~A}$ \\
\cline { 2 - 8 } & $\begin{array}{c}1 / 5^{\text {th }} \\
\left(\mathrm{LC}_{50}\right)\end{array}$ & 0.038 & $1.59 \pm 0.03 \mathrm{D}$ & 0.06 & $1.67 \pm 0.03 \mathrm{D}$ & 0.041 & $1.76 \pm 0.02 \mathrm{D}$ \\
\cline { 2 - 8 } & $\begin{array}{c}1 / 10^{\text {th }} \\
\left(\mathrm{LC}_{50}\right)\end{array}$ & 0.019 & $3.37 \pm 0.04 \mathrm{C}$ & 0.03 & $2.14 \pm 0.02 \mathrm{C}$ & 0.020 & $3.05 \pm 0.03 \mathrm{C}$ \\
\cline { 2 - 8 } & $\begin{array}{c}1 / 15^{\text {th }} \\
\left(\mathrm{LC}_{50}\right)\end{array}$ & 0.012 & $5.28 \pm 0.02 \mathrm{~B}$ & 0.02 & $6.45 \pm 0.02 \mathrm{~B}$ & 0.013 & $4.13 \pm 0.06 \mathrm{~B}$ \\
\hline
\end{tabular}


Table 2. Effect of sublethal concentrations of profenofos on proximate composition (percentage) of muscle of control and treated groups of major Indian carp.

\begin{tabular}{|c|c|c|c|c|c|c|}
\hline Fish Spp. & Treatments $(\mathrm{mg} / \mathrm{L})$ & Moisture & Protein & Fat & Ash & Carbohydrates \\
\hline \multirow{4}{*}{\begin{tabular}{c} 
Catla catla \\
\cline { 2 - 7 }
\end{tabular}} & Control & $76.72 \pm 0.04 \mathrm{D}$ & $18.59 \pm 0.04 \mathrm{~A}$ & $1.46 \pm 0.15 \mathrm{~A}$ & $1.65 \pm 0.03 \mathrm{D}$ & $1.75 \pm 0.04 \mathrm{~A}$ \\
\cline { 2 - 7 } & 0.038 & $82.33 \pm 0.03 \mathrm{~A}$ & $12.76 \pm 0.04 \mathrm{D}$ & $0.67 \pm 0.04 \mathrm{C}$ & $4.06 \pm 0.01 \mathrm{~A}$ & $0.38 \pm 0.01 \mathrm{~B}$ \\
\cline { 2 - 7 } & 0.019 & $80.16 \pm 0.04 \mathrm{~B}$ & $13.92 \pm 0.05 \mathrm{C}$ & $0.84 \pm 0.05 \mathrm{BC}$ & $3.60 \pm 0.02 \mathrm{~B}$ & $1.59 \pm 0.02 \mathrm{~A}$ \\
\hline \multirow{4}{*}{$\begin{array}{c}\text { Labeo } \\
\text { rohita }\end{array}$} & 0.012 & $78.87 \pm 0.03 \mathrm{C}$ & $15.89 \pm 0.21 \mathrm{~B}$ & $0.96 \pm 0.05 \mathrm{~B}$ & $2.39 \pm 0.04 \mathrm{C}$ & $1.74 \pm 0.05 \mathrm{~A}$ \\
\cline { 2 - 7 } & 0.06 & $77.44 \pm 0.06 \mathrm{D}$ & $19.18 \pm 0.02 \mathrm{~A}$ & $1.65 \pm 0.06 \mathrm{~A}$ & $0.89 \pm 0.04 \mathrm{C}$ & $1.20 \pm 0.01 \mathrm{~B}$ \\
\cline { 2 - 7 } & 0.03 & $81.24 \pm 0.01 \mathrm{~B}$ & $15.14 \pm 0.029 \mathrm{C}$ & $0.75 \pm 0.01 \mathrm{C}$ & $2.70 \pm 0.01 \mathrm{~A}$ & $0.58 \pm 0.04 \mathrm{C}$ \\
\hline \multirow{4}{*}{$\begin{array}{c}\text { Cirrhinus } \\
\text { mrigala }\end{array}$} & 0.02 & $79.16 \pm 0.03 \mathrm{C}$ & $16.17 \pm 0.024 \mathrm{~B}$ & $1.06 \pm 0.20 \mathrm{~B}$ & $1.89 \pm 0.01 \mathrm{~B}$ & $1.94 \pm 0.06 \mathrm{~A}$ \\
\cline { 2 - 7 } & 0.020 & $80.14 \pm 0.02 \mathrm{D}$ & $14.62 \pm 0.02 \mathrm{~A}$ & $1.781 \pm 0.02 \mathrm{~A}$ & $1.95 \pm 0.03 \mathrm{C}$ & $1.71 \pm 0.01 \mathrm{~A}$ \\
\cline { 2 - 7 } & 0.013 & $84.66 \pm 0.01 \mathrm{C}$ & $11.34 \pm 0.03 \mathrm{~B}$ & $1.25 \pm 0.02 \mathrm{~B}$ & $1.79 \pm 0.02 \mathrm{D}$ & $1.14 \pm 0.02 \mathrm{~B}$ \\
\hline
\end{tabular}

Means with different letters for each fish and each constituent (content \%) in a column are highly significantly different $(\mathrm{P}<0.01)$; S.E. $=$ standard error

In this study, decreases in protein, fat, and carbohydrate contents were recorded against different sublethal doses of profenofos in these three fish species (Table 2). In C. catla, Labeo rohita, and C. mrigala minimum crude protein percentages were observed as $82.29 \pm 0.031, \quad 84.17 \pm 0.12$, and $86.99 \pm 0.02$ when exposed to $0.038 \mathrm{mg} / \mathrm{L}, 0.06 \mathrm{mg} / \mathrm{L}$, and $0.041 \mathrm{mg} / \mathrm{L}$ of profenofos, respectively. In $L$. rohita more depletion in protein contents was observed against the exposure of $0.06 \mathrm{mg} / \mathrm{L}$ of profenofos (Table 2). A highly significant $(\mathrm{P}<0.01)$ difference in total lipid contents in treated and control groups was recorded in $C$. catla, $L$. rohita, and $C$. mrigala. The minimum decrease in fat and carbohydrate was recorded when exposed to the concentration of $0.012,0.02$, and $0.013 \mathrm{mg} / \mathrm{L}$ in these fish species (Table 2). Ash contents showed an irregular pattern of an increase or decrease in these fish species against various concentrations of this insecticide. In $C$. catla, the rise in the level of ash contents was recorded as: control $<0.012 \mathrm{mg} / \mathrm{L}$ $<0.019 \mathrm{mg} / \mathrm{L}<0.038 \mathrm{mg} / \mathrm{L}$. In $L$. rohita and C. mrigala the increase in ash was recorded as control $<0.02 \mathrm{mg} / \mathrm{L}<0.06 \mathrm{mg} / \mathrm{L}<0.03 \mathrm{mg} /$ and $0.013 \mathrm{mg} / \mathrm{L}<$ control $<0.020 \mathrm{mg} / \mathrm{L}<0.041 \mathrm{mg} / \mathrm{L}$, respectively. Highly significant $(\mathrm{P}<0.01)$ differences were recorded between the treated and control groups of fish (Table 2). The overall comparison for proximate constitutes in the muscle samples of $C$. catla, $L$. rohita, and $C$. mrigala exhibited highly significant $(\mathrm{P}<0.01)$ differences among all the constituents of proximate composition and among the various sublethal concentrations of profenofos and the control group (Tables 2). These sublethal doses significantly caused a stress in C. catla, L. rohita, and C. mrigala, which affected the nutritive components of fish muscles. [20] argued that water contaminants have a negative effect on the accumulation of protein and carbohydrates. The exposure of fish to various concentration of Profenofos caused an increase in the moisture percentage and was found to be inversely related to each other. In this study, the increase in the fish exposed to sublethal concentration of this insecticide caused a decrease in protein, lipids, and carbohydrates, which indicates poor growth of fish and vice versa [21-22]. The nutritive contents of proximate composition were declined significantly $(\mathrm{P}<0.01)$ against the sublethal test doses of pesticide compared to control fish. [16] reported similar findings for these constituents when the fish were given different sublethal doses of monocrotophos. The fish under toxicant stress started the utilization of immediate sources of energy like protein, lipid, and carbohydrate, resultantly depleting the levels of these nutritive sources in the muscles as these all are interrelated in metabolism during the citric acid cycle [16, 23-25]. [23] mentioned the maximum decrease in protein content against the highest dose of monocrotophos. In this study, the protein contents depletion in the fish muscle might be because of diversion of energy due to the toxic stress of profenofos [7, 16, 25-26]. [27] observed a decrease in protein in L. rohita after exposure to chlorpyrifos. [28] reported that unexposed fish might exhibit better nutritional composition compared to the fish treated with chlorpyrifos, which might be due to their better health and balance protein and lipid profile in the muscle of Clarias gariepinus. [29] reported a decrease in protein and fat content against sublethal exposure of 'Phorate $10 \mathrm{G}$ ' in tilapia. The moisture and total ash 
Table 3. Effect of sublethal concentrations of profenofos on maximum allowable toxicant concentration (MATC) values worked out on the proximate composition in major Indian carp.

\begin{tabular}{|c|c|c|c|c|c|c|}
\hline Fish species & Energy component & $\begin{array}{l}\text { NOEC } \\
(\mathrm{ppm})\end{array}$ & $\begin{array}{l}\text { LOEC } \\
(\mathrm{ppm})\end{array}$ & $\begin{array}{l}\text { MATC } \\
(\mathrm{ppm})\end{array}$ & $\begin{array}{l}48 \text { h LC50 } \\
\text { (ppm) }\end{array}$ & $\mathrm{AF}=\underline{48 \mathrm{MATC}}$ \\
\hline \multirow{5}{*}{ Catla catla } & Moisture & 0.012 & 0.019 & 0.151 & 0.29 & 0.52 \\
\hline & Protein & 0.012 & 0.019 & 0.151 & “ & 0.52 \\
\hline & Fats & 0.012 & 0.019 & 0.151 & “ & 0.52 \\
\hline & Ash & 0.012 & 0.019 & 0.151 & “ & 0.52 \\
\hline & Carbohydrate & 0.019 & 0.038 & 0.027 & “ & 0.09 \\
\hline \multirow{5}{*}{ Labeo rohita } & Moisture & 0.02 & 0.03 & 0.024 & 0.44 & 0.054 \\
\hline & Protein & 0.02 & 0.03 & 0.024 & “ & 0.054 \\
\hline & Fats & 0.02 & 0.03 & 0.024 & “ & 0.054 \\
\hline & Ash & 0.02 & 0.06 & 0.024 & “ & 0.054 \\
\hline & Carbohydrate & 0.03 & 0.06 & 0.042 & “ & 0.095 \\
\hline \multirow{5}{*}{ Cirrhinus mrigala } & Moisture & 0.013 & 0.020 & 0.016 & 0.25 & 0.064 \\
\hline & Protein & 0.013 & 0.020 & 0.016 & “ & 0.064 \\
\hline & Fats & 0.013 & 0.020 & 0.016 & “ & 0.064 \\
\hline & Ash & 0.013 & 0.020 & 0.016 & “ & 0.064 \\
\hline & Carbohydrate & 0.013 & 0.020 & 0.016 & “ & 0.076 \\
\hline
\end{tabular}

$\mathrm{NOEC}=$ no observed effect concentration, $\mathrm{LOEC}=$ lowest observed effect concentration, MATC $=$ maximum allowable toxicant concentration

content was increased after exposure to this pesticide. The rise in moisture percentage may be because of reorganization in the energy sources, whereas the increase in lipid amount showed the substitute mechanism to overcome the pesticide stress [25]. Our findings were inconsistent with the above-mentioned works. Carbohydrate percentage was significantly decreased after the exposure of C. catla, L. rohita, and $C$. mrigala with different doses of profenofos. The results of this investigation were inconsistent with the findings of [30-31]. Carbohydrates were significantly affected by the exposure dose of 0.019 and $0.03 \mathrm{mg} / \mathrm{L}$ in C. catla and L. rohita, respectively (Table 2).

MATC was calculated on the basis of no observed effect concentration on the proximate composition (NOEC) and LOEC and presented in Table 3. In this investigation, the MATC end point of carbohydrates in $C$. catla and L. rohita were comparatively more sensitive compared to protein, fat, and ash contents against the exposure doses of 0.019 and $0.03 \mathrm{mg} / \mathrm{L}$ of profenofos, respectively (Table 3). MATC endpoints in C. mrigala presented non-significant differences in protein, lipids, carbohydrates, and ash contents (Table 3). These biomarkers can be successfully used as an early warning of a change in these freshwater fish species. The application factors (AF) determined through the controlled experiments may be used as a bioindicator of field conditions. The non-migratory nature of the major Indian carp made them more vulnerable and exposed to different contaminants discharged untreated from different sources into the freshwater ecosystems in the country.

\section{Conclusions}

The chronic application of sublethal concentrations of profenofos for a longer period of time is harmful to the fish and may induce changes in the nutritive constituents of proximate composition of fish muscle. It is proposed that the alteration in protein, fat, ash, and carbohydrate may be used as a biomarker to assess the level of pesticide stress. The information ascertained through these studies may be useful in regulating these toxicants. The application factor (AF) calculated in the laboratory experiment may be directly applied to the field situations. Knowing the value of AF for one pesticide, the MATC for other relevant insecticides can easily be worked if its 48-hr LC50 (lethal concentration) is known.

\section{Acknowledgements}

Authors Ghazala and S.M. would like to express thanks for financial support to the first author for her Ph.D. degree by the Higher Education Commission of Pakistan. Author KAG would like to express sincere 
appreciation to the dean of scientific research at King Saud University for funding this research through the Research Group Project (Prolific Research Group No. 1436-011).

\section{Conflict of Interest}

The authors declare no conflict of interest.

\section{Ethical Guidelines}

The standard guidelines for animal experiments prepared by the department and the university were followed in this study.

\section{References}

1. BAQAR M., SADAF Y., AHMAD S. R. MAHMOOD A., LI J., ZHANG G. Organochlorine pesticides across the tributaries of River Ravi, Pakistan: Human health risk assessment through dermal exposure, ecological risks, source fingerprints and spatio-temporal distribution. Science of the Total Environment 618, 291, 2018.

2. RAMESH M., NARMADHA S. POOPAL R.K. Toxicity of furadan (carbofuran $3 \% \mathrm{~g}$ ) in Cyprinus carpio: Haematological, biochemical and enzymological alterations and recovery response. Beni - Suefuni Univ. Journal of Basic and Applied Science, 4, 314, 2015.

3. SULEKHA B.T. Mercy T.V.A. Pesticide-induced histopathological changes in the freshwater fishes of Kuttanand, Kerala - A tool to assess water quality and the health status of fishes. Asian Fish. Science, 22, 729, 2009.

4. BURKEPILE D.E., MOORE M.T., HOLLAND M.M. Susceptibility of five non target organisms to aqueous diazinon exposure. Bulletin of Environmental Contamination and Toxicology, 64 (1), 114, 2000. doi:10.1007/s001289910018

5. SARAVANAN M., PRABHU K., RAMESH M. Haematological and biochemical responses of freshwater teleost fish Cyprinus carpio (Actinopterygii: Cypriniformes) during acute and chronic sublethal exposure to lindane. Pesticide Biochemistry Physiology, 100 (3), 206, 2011. doi:10.1016/j.pestbp.2011.04.002.

6. PETER V.S., BABITHA G.S., BONGA S.E., PETER M.C. Carbaryl exposure and recovery modify the internal and thyroidal activities and the mitochondria-rich cell function in the climbing perch Anabas testudineus Bloch. Aquatic Toxicology, 126, 306, 2013. doi:10.1016/j. aquatox.2012.09.014.

7. SWEILUM M.A. Effect of sublethal toxicity of some pesticides on growth parameters, haematological properties and total production of Nile tilapia (Oreochromis niloticus L.) and water quality of ponds. Aquaculture Research, 37, 1079, 2006

8. PIMPAO C.T., ZAMPRONIO A.R. de ASSIS H.C.S. Effects of deltamethrin on hematological parameters and enzymatic activity in Ancistrus multispinis (Pisces, Teleostei). Pesticide Biochemistry and Physiology, 88, 1227, 2007. doi:10.1016/j.pestbp.2006.10.002.

9. PALANICHANY S., MALLIGADEVI T. ARUNACHALAM S. Sublethal effects of thiodon and ekalux on food utilization, growth and conversion efficiency in the fish Lepidocephalicthys thermalis. Uttar Pradesh Journal of Zoology, 6, 58, 1987.

10. NOWELL L.H., NORMAN J.E., MORAN P.W., MARTIN J.D., STONE W.W. Pesticide toxicity index - A tool for assessing potential toxicity of pesticide mixtures to freshwater aquatic organisms. Science of Total Environment, 476-477, 144, 2014.

11. SRINIVASA R.P., BABU B.N., RAJU R.R. Study the effect of chlorpyrifos on proteins in freshwater fish Labeo rohita by using HPLC method. International Journal Pharmaceutical and Biomedical Science 1 (1), 1, 2010.

12. VIJAYARGHAVAN G., S. Carbohydrate metabolism in hepatic tissue of freshwater catfish Clarias batrachus L. during dimethoate exposure. Food Chemical Toxicology, 33 (5), 423, 1995.

13. SCHNEIDER W.C. Determination of nucleic acids in tissues by pentose analysis. In: COLOWICK, S. P. AND N. O. KAPLAN, eds., Methods in enzymology. Academic Press, New York, 3, 1, 1957.

14. AOAC (Association of official analytical Chemistry). Official methods of analysis, $18^{\text {th }}$ ed. Williams, S. ed., AOAC, Inc., Arlington, Virginia. 1995.

15. MOUNT D.I., STEPHEN C.E. A method for establishing acceptable toxicant limits for malathion in fish. Trans. Am. Fish. Soc., 96, 185, 1967.

16. SULEKHA B.T., MERCY T.V.A. Pesticide induced changes in the proximate composition of a freshwater fish for estimating maximum allowable toxicant concentration of the pesticide under tropical conditions. Indian Journal of Fisheries, 58, 85, 2011.

17. SHARBIDRE A.A., METKARI V., PATODE P. Effect of methyl parathion and chlorpyrifos on certain biomarkers in various tissues of guppy fish, Poecilia reticulate. Pesticide Biochemistry and Physiology, 101 (2), 132, 2011. doi:10.1016/j.pestbp.2011.09.002.

18. THENMOZHI C., V. VIGNESH, R., THIRUMURGAN, S. A. Impacts of malathion on mortality and biochemical changes of freshwater fish Labeo rohita, Iranian Journal Environmental Health Science Engineering, 8 (4), 387, 2011.

19. NUTAN D.R. RAVINDRA V.K. Quantification of nuclecic acid from freshwater fish Punctius arenatus (Day) exposed to pesticides. International Journal of Advanced Biotechnology and Research, 1, 43, 2010.

20. ALAMDAR A., SYED J.H., MALIK R.N., KATSOYIANNIS A., LIU J., LI J., ZHANG G., JONES K.C. Organochlorine pesticides in surface soils from obsolete pesticide dumping ground in Hyderabad City, Pakistan: contamination levels and their potential for air-soil exchange. Science of Total Environment, 470, 733, 2014.

21. MAHMOOD A., MALIK R.N., LI J., ZHANG G. Human health risk assessment and dietary intake of organochlorine pesticides through air, soil and food crops (wheat and rice) along two tributaries of river Chenab, Pakistan. Food Chemistry Toxicology, 71, 17, 2014.

22. JAVED M. Heavy metal contamination of freshwater fish and bed sediments in the river Ravi stretch and related tributaries. Pakistan Journal of Biological Science, 8 (10), 1337, 2005.

23. BUTT K. Histopathological study of liver, gills and intestine in Labeo rohita from River Ravi. M. Sc thesis Department of Zoology, GC University, Faisalabad.

24. BOSE S., NAITH S., SAHNA S.S. Toxic impact of thiamethoxam on the growth performance and liver 
protein concentration of a freshwater fish Oreochromis niloticus (Trewavas). Indian Journal Fundamental Applied Life Science, 1, 274, 2011.

25. MURALIDHARAN L. Chronic toxicity studies on proximate composition of Cyprinus carpio exposed to fenthion. International Journal of Fisheries and Aquatic Studies, 1 (5), 221, 2014.

26. KARAMI A., GOH Y.M., JAHROMI M.F., LAZORCHAK J.M., ABDULLAH M. COUTENY S.C. Diploid and triploid African catfish (Clarias gariepinus) differ in biomarker responses to the pesticide chlorpyrifos. Science of Total Environment, 557-558, 204, 2016.

27. RAO P.S., BABU N.B., RAJU R.R. Study the effect of chlorpyrifos on proteins in fresh water fish Labeo rohita by using HPLC method. International Journal Research Pharmaceutical Biomedical Science, 1, 5, 2010.

28. SAMNANEH K., ALI K., MAHDI E., MOHAMMAD F.J., AMIN I., JUAN B.L., STUART L.S., SHARIFAH N.S.I., YONG-MMENG G. Changes in nutritional parameters in diploid and triploid African catfish Clarias gariepinus following chlorpyrifos exposure. Aquatic Biology, 26, 101, 2017 https://doi.org/10.3354/ab00678

29. SANA K.M.P., INDULKAR S.T., LATEEF A.H.S., PAI R. Lethal and sublethal Toxicity of an organophosphate pesticide, phorate $10 \mathrm{G}$ on fingerlings of tilapia Sp. International Journal Pure Applied Bioscience 5 (2), 1153, 2017.

30. DHASARATHAN P., PALANIAPPAN R., SINGH A.J.A.R. Effect of endosulfan and butachlor on the digestive enzyme and proximate composition of the fish Cyprinus carpio. Indian Journal Environmental Ecoplanning, 3, 611, 2000.

31. VENKATESHWARUL M., SHIVANAGOUDA N., SYED S. Influence of carbaryl on the carbohydrate levels in the tissues of common carp, Cyprinus carpio. Toxicological Environmental Chemistry, 93, 279, 2011. 
